\title{
Serum lactate dehydrogenase: a prognostic factor in pre-eclampsia
}

\author{
Meena Mehta1, Meetali Parashar ${ }^{1 *}$, Rajesh Kumar²
}

${ }^{1}$ Department of Obstetrics and Gynecology, RIMS, Ranchi, Jharkhand, India

${ }^{2}$ Department of Community Medicine, RIMS, Ranchi, Jharkhand, India

Received: 06 May 2019

Accepted: 11 June 2019

\section{*Correspondence:}

Dr. Meetali Parashar,

E-mail: mparashar04@gmail.com

Copyright: () the author(s), publisher and licensee Medip Academy. This is an open-access article distributed under the terms of the Creative Commons Attribution Non-Commercial License, which permits unrestricted non-commercial use, distribution, and reproduction in any medium, provided the original work is properly cited.

\section{ABSTRACT}

Background: Pre eclampsia is responsible for significant maternal and perinatal morbidity and mortality worldwide .Serum LDH level is a useful biomarker for cellular injury which may reflect the severity of pre eclampsia and its level might be a guideline for management of patients. The aim of study was to find out the role of serum LDH in prediction of adverse outcome of pre eclampsia, severity of disease and occurrence of complications.

Methods: This prospective observational study was conducted in the department of Obstetrics and Gynecolog, RIMS, Ranchi, Jharkhand, India. A total of 300 cases were studied.150 cases were non severe preeclamptic and 150 cases were severe pre eclamptic patients. Serum LDH was done in both non severe and severe eclamptic patients .Data entry was done in Microsoft excel 2007. Results were analysed by chi square test.

Results: Higher LDH levels had significant correlation with high blood pressure as well as poor maternal and perinatal outcome.

Conclusions: High serum LDH level correlate well with the severity of disease and poor outcome in patients of pre eclampsia. Detection of high risk patients with increased levels of LDH mandate close monitoring and management to prevent maternal and fetal morbidity and mortality.

Keywords: Maternal morbidity, Maternal mortality, Non severe pre eclampsia, Serum LDH, Severe pre eclampsia

\section{INTRODUCTION}

Hypertensive disorders of pregnancy and their complications rank as one of the major cause of maternal mortality and morbidity in the world after obstetric hemorrhage, pre existing medical disorders, sepsis and abortions. It complicates 5-10\% of all pregnancies.

In India, maternal mortality due to eclampsia which is a fatal complication of pre eclampsia, is very high, varying from 2 to $30 \%$ and perinatal mortality occurs in $20 \%$ of cases, $50 \%$ of which is stillborn. These are largely preventable and once detected are treatable at early stage.
Hypertensive disorders of pregnancy covers a spectrum of clinical conditions namely pre-eclampsia, eclampsia, gestational hypertension, chronic hypertension and preeclampsia/ eclampsia superimposed on chronic hypertension. Pre-eclampsia is divided into severe and non severe varieties.

Non severe pre-eclampsia includes cases of sustained rise of blood pressure $>140 / 90 \mathrm{mmHg}$ but less than $160 / 110$ $\mathrm{mm} \mathrm{Hg}$ without significant proteinuria and patient does not have any of the signs and symptom associated with severe PE. Severe PE is a condition where systolic BP remains $160 \mathrm{~mm} \mathrm{Hg}$ or higher or diastolic pressure 
remains $110 \mathrm{mmHg}$ or higher and/or associated with any organ damage.

- Thrombocytopenia

- $\quad$ Platelet $<1 \mathrm{lac} / \mathrm{mm}^{3}$

- $\quad$ Impaired LFT(elevated liver enzymes)

- $\quad$ Progressive renal insufficiency

- Pulmonary edema

- New onset cerebral/visual disturbance

Pre-eclampsia when complicated with grand mal seizures (generalized tonic tonic convulsion) is called eclampsia.

Pre-eclampsia is one of the leading causes of maternal mortality and morbidity second only to PPH. It is the most important and common medical complication of pregnancy. Mortality in pre-eclampsia is just a tip of iceberg, what lies beneath is the near miss morbidity. For every maternal death, there are 50-100 women who experience near miss significant morbidity that results in significant health risk and health care costs.

Increased maternal deaths are mainly related to eclampsia, accidental hemorrhage, acute renal failure, pulmonary edema, DIC and HELLP syndrome. The most common causes of fetal death are prematurity, fetal asphyxia and acidosis. With prompt and effective treatment, the pre-eclamptic feature subsides completely and the prognosis is unfavourable, both for mother and baby. However if the cases are left uncared for, serious complications are likely to occur. Lactate Dehydrogenase (LDH) is mainly intracellular enzyme in pre-eclampsia and eclampsia where massive intracellular death occurs. $\mathrm{LDH}$ is a very good marker to detect disease severity and can indicate prognosis for both mother and fetus.

The present study was designed to correlate the severity of the disease, maternal and perinatal outcome with serum LDH levels in patients of pre-eclampsia. This can be further used as a help in making decision regarding the management strategies to improve the maternal and fetal outcome.

The aim of the study was to find out the role of serum LDH in prediction of adverse outcome of pre eclampsia; severity of disease and occurrence of complications.

\section{METHODS}

This study was a hospital based observational study done from January 2017 to December 2018 in the department of obstetrics and gynaecology of RIMS, Ranchi, Jharkhand, India. A total of 150 severe pre-eclampsia patients were selected from admitted patient of preeclampsia in labour room who has given consent. Also 150 non severe pre-eclampsia patients were selected. Total 300 patients were included. All cases of eclampsia and hypertensive pregnant women of gestational age < 20 weeks, pregnant women with history of smoking, alcoholism, diabetes mellitus, chronic hypertension, cardiac, liver or lung disease, multiple and molar pregnancy were excluded from the study. Detailed history was taken and proper examination done after taking informed consent from the patient. Parameters like patient's age, area of residence, obstetric history, booking status were noted. Serum LDH was investigates of each patient. All patients where followed up till discharge and Serum LDH was done in each case. Serum LDH was compared in both non severe and severe cases of preeclampsia.

\section{Statistical analysis}

Data entry was done in Microsoft Excel 2007 software. For analysis Chi square test was used for comparing the mean LDH level with the maternal and perinatal outcomes. $p$ value less than 0.05 was significant.

\section{RESULTS}

The Table 1 shows age distribution. 101 patients $(76.3 \%)$ from non severe pre-eclampsia and 94 patients $(62.6 \%)$ from severe pre-eclampsia belonged to 18-25 years of age followed by $39(26 \%)$ patients from non severe preeclampsia and $41(27 \%)$ from severe pre-eclampsia in the $25-30$ years of age group. $($ Chi square $=1.301, \mathrm{P}$ value $=$ $0.521)$.It clearly shows that maximum cases of pre eclampsia is seen in the age group of maximum fertility and when female become pregnant for the first time that is 18-30 years. Less number of pre-eclampsia cases seen in age $>30$ indicates increasing parity as primigravida is an important risk factor of pre-eclampsia in Jharkhand. In our study, $\mathrm{p}$ value was not significant but proportionately, it was found to be significant.Table 2 shows background of the patients. 105 patients $(70 \%)$ with non severe preeclampsia and $114(76 \%)$ with severe pre-eclampsia were from rural background. (Chi square $=1.37, \mathrm{P}$ value $=$ 0.241). It shows that most of the pregnant female having pre-eclampsia come from rural areas of Jharkhand.

Table 1: Age distribution.

\begin{tabular}{|c|c|c|c|c|}
\hline Age group & Non severe pre- eclampsia & Severe pre-eclampsia & Total & \multirow{5}{*}{$\begin{array}{l}\text { Chi square }=1.301, \\
\text { P value } \\
=0.521\end{array}$} \\
\hline $18-25$ years & $101(76.3 \%)$ & $94(62.6 \%)$ & 195 & \\
\hline $25-30$ years & $39(26 \%)$ & $41(27.3 \%)$ & 80 & \\
\hline$>30$ years & $10(6.6 \%)$ & $15(10 \%)$ & 25 & \\
\hline Total & 150 & 150 & 300 & \\
\hline
\end{tabular}

Table 2: Rural /urban distribution. 


\begin{tabular}{|lllll|}
\hline Area distribution & Non severe pre-eclampsia & Severe pre-eclampsia & Total & \\
\hline Rural & $105(70 \%)$ & $114(76 \%)$ & 219 & Chi square $=1.37$ \\
\hline Urban & $45(30 \%)$ & $36(24 \%)$ & 81 & P value $=0.241$ \\
\hline Total & $\mathbf{1 5 0}$ & $\mathbf{1 5 0}$ & $\mathbf{3 0 0}$ & \\
\hline
\end{tabular}

Table 3: Booking status.

\begin{tabular}{|lllll|}
\hline & Non severe pre eclampsia & Severe pre eclampsia & Total & Chi square $=$ \\
\hline Booked & $37(24.6 \%)$ & $22(14.6 \%)$ & 59 & 4.747, \\
\hline Unbooked & $113(75.3 \%)$ & $128(85.3 \%)$ & 241 & P value $=0.0293$ \\
\hline Total & $\mathbf{1 5 0}$ & $\mathbf{1 5 0}$ & $\mathbf{3 0 0}$ & . \\
\hline
\end{tabular}

Still a large population of pregnant female of Jharkhand are unbooked. Table 3 shows that $113(75.3 \%)$ patients from non severe pre-eclampsia and 128 patients $(85.3 \%)$ from severe pre-eclampsia were unbooked (Chi square $=$ $4.747, \mathrm{P}$ value $=0.0293$ ). No antenatal check up or poor antenatal check up is the reason for the uncontrolled hypertension and landing of these unbooked cases into preeclampsia and its complications. It is to be emphasized that only 37 patients $(24.6 \%)$ from non severe pre-eclampsia and 22 patients $(14.6 \%)$ from severe preeclampsia were booked whereas government aims to provide antenatal check up to $100 \%$ of the patients.

Primigravida (young or elderly) who are first time exposed to chorionic villi are more likely to have pre eclampsia. Table 4 shows that most patients in both non severe $(56 \%)$ and severe pre-eclampsia $(81 \%)$ were primigravida $($ Chi square $=1.055, \mathrm{P}$ value $=0.787)$.

Table 4: Distribution according to gravidity.

\begin{tabular}{|llll|}
\hline Gravida & Non severe pre eclampsia & Severe pre-eclampsia & Total \\
\hline Primigravida & $84(56 \%)$ & $81(54 \%)$ & 165 \\
\hline $2^{\text {nd }}$ gravida & $28(18.6 \%)$ & $35(23.3 \%)$ & 63 \\
\hline $3^{\text {rd }}$ gravida & $19(12.6 \%)$ & $17(11.3 \%)$ & 36 \\
\hline $4^{\text {th }}$ gravida or more & $19(12.6 \%)$ & $17(11.3 \%)$ & 36 \\
\hline Total & $\mathbf{1 5 0}$ & $\mathbf{1 5 0}$ & $\mathbf{3 0 0}$ \\
\hline
\end{tabular}

Table 5: Serum LDH levels in different groups.

\begin{tabular}{|lllll|}
\hline Sr LDH levels $($ IU/L $)$ & Non severe pre-eclampsia & Severe pre-eclampsia & Total \\
\hline$<600 \mathrm{IU} / \mathrm{L}$ & $56(37.3 \%)$ & $00(0 \%)$ & 56 & Chi square $=$ \\
\hline $600-800 \mathrm{IU} / \mathrm{L}$ & $58(38.6 \%)$ & $56(37.3 \%)$ & 114 & $\mathbf{8 1 . 9 1 2 ,}$ \\
\hline$>800 \mathrm{IU} / \mathrm{L}$ & $36(24 \%)$ & $94(62.6 \%)$ & 130 & P value $=0.0102$ \\
\hline Total & $\mathbf{1 5 0}$ & $\mathbf{1 5 0}$ & $\mathbf{3 0 0}$ & \\
\hline
\end{tabular}

Table 6: Gestational age at the time of delivery.

\begin{tabular}{|c|c|c|c|c|}
\hline Gest age & Non severe pre-eclampsia & Severe pre-eclampsia & Total & \multirow{5}{*}{$\begin{array}{l}\text { Chi square }= \\
9.168, \\
P \text { value }=0.0102\end{array}$} \\
\hline $20-<28$ weeks & $00(0 \%)$ & $03(2 \%)$ & 03 & \\
\hline$\geq 28-<37$ weeks & $30(20 \%)$ & $48(32 \%)$ & 78 & \\
\hline$\geq 37$ weeks & $120(80 \%)$ & $99(66 \%)$ & 219 & \\
\hline Total & 150 & 150 & 300 & \\
\hline
\end{tabular}

Table 5 depicts that $62.6 \%$ of the severe pre-eclampsia patients and $24 \%$ of non severe pre-eclampsia had serum LDH levels > $800 \mathrm{IU} / \mathrm{L}$ showing that as the severity of pre eclampsia increases, so does the level of serum $\mathrm{LDH}$. (Chi square $=81.912, \mathrm{P}$ value $=0.0102$ ) .
The incidence of preeclampsia increases with advanced gestational age. Table 6 shows most of the patients at the time of delivery in both non severe $(80 \%)$ and severe pre eclampsia $(66 \%)$ had gestational age $\geq 37$ weeks while 
only $3(2 \%)$ cases were of gestational age $20-<28$ weeks

$($ Chi square $=9.168, \mathrm{p}$ value $=0.0102)$

Table 7: Gestational age in relation to level of serum LDH (IU/L).

\begin{tabular}{|llllll|}
\hline Gest age & $<600 \mathrm{IU} / \mathrm{L}$ & $600-800 \mathrm{IU} / \mathrm{L}$ & $>800 \mathrm{IU} / \mathrm{L}$ & Total \\
\hline $20-<28$ weeks & $00(0 \%)$ & $01(33 \%)$ & $02(66.6 \%)$ & 03 & Yates' chi square = \\
\hline$\geq 28-<37$ weeks & $08(9.87 \%)$ & $22(27.1 \%)$ & $51(62.9 \%)$ & 81 & 36.085 \\
\hline$\geq 37$ weeks & $89(41.2 \%)$ & $67(31 \%)$ & $60(27.7 \%)$ & 216 & Yates' p value =2.8 \\
\hline Total & $\mathbf{9 7}$ & $\mathbf{9 0}$ & $\mathbf{1 1 3}$ & $\mathbf{3 0 0}$ & \\
\hline
\end{tabular}

Table 8: Labour onset in relation to level of serum LDH (IU/L).

\begin{tabular}{|llllll|}
\hline & $<600 \mathrm{IU} / \mathrm{L}$ & $600-800 \mathrm{IU} / \mathrm{L}$ & $>800 \mathrm{IU} / \mathrm{L}$ & Total & Chi square $=$ \\
\hline Spontaneous & $88(97.7 \%)$ & $69(78.4 \%)$ & $84(68.8 \%)$ & 241 & 27.72 \\
\hline Induced & $2(2.2 \%)$ & $19(21.5 \%)$ & $38(31.1 \%)$ & 59 & P value $=9.6$ \\
\hline Total & $\mathbf{9 0}$ & $\mathbf{8 8}$ & $\mathbf{1 2 2}$ & $\mathbf{3 0 0}$ & . \\
\hline
\end{tabular}

As the gestational age increases, the level of serum LDH also increases. It is evident from Table 7 that $60(27.7 \%)$ patients had a gestational age of $\geq 37$ weeks with serum LDH level >800 IU/L (Yates' chi square $=36.085$, Yates' $\mathrm{p}$ value $=2.8$ ).

Table 8 shows that 241 patients went into spontaneous labour whereas 59 patients were induced irrespective of serum LDH level showing no significant correlation (Chi square $=27.72$, $\mathrm{p}$ value $=9.6$ ).

Table 9 shows the comparison of blood pressure with serum LDH levels. 123 patients had a systolic blood pressure $\geq 160 \mathrm{mmHg}$, out of which 77 (62.6\%) had a serum LDH levels $>800 \mathrm{IU} / \mathrm{L} 114$ patients had a diastolic blood pressure $\geq 110 \mathrm{mmHg}$, out of which $74(64.9 \%)$ had a serum LDH level > 800 IU/L $($ Chi square $=196.72$, $\mathrm{p}$ value $=0)$.

Table 10 shows the comparison of serum LDH level with birth weight of babies. There was no statistically significant correlation (Yates' chi square $=33.68$, Yates' $p$ value $=8.7)$ but in the group of babies with birth weight $<1.5 \mathrm{~kg}, 9$ cases $(69.2 \%)$ had serum LDH levels $>800$ IU/L which was proportionately significant.

Table 9: Blood pressure in relation to level of serum LDH (IU/L).

\begin{tabular}{|c|c|c|c|c|c|c|}
\hline \multicolumn{2}{|c|}{ BP (mmHg) } & $<600 \mathrm{IU} / \mathrm{L}$ & 600-800 IU/L & $>800 \mathrm{IU} / \mathrm{L}$ & Total & \multirow{9}{*}{$\begin{array}{l}\text { Chi square = } \\
196.72 \\
\text { P value = } 0\end{array}$} \\
\hline \multirow{4}{*}{ Systolic } & $<140$ & $62(66.6 \%)$ & $14(15 \%)$ & $17(18.2 \%)$ & 93 & \\
\hline & $\geq 140-160$ & $26(30.9 \%)$ & $30(35.7 \%)$ & $28(33.3 \%)$ & 84 & \\
\hline & $\geq 160$ & $4(3.2 \%)$ & $42(34.1 \%)$ & $77(62.6 \%)$ & 123 & \\
\hline & Total & 92 & 86 & 122 & 300 & \\
\hline \multirow{4}{*}{ Diastolic } & $<90$ & $48(66.6 \%)$ & $13(18.0 \%)$ & $11(15.2 \%)$ & 72 & \\
\hline & $\geq 90-110$ & $40(35 \%)$ & $39(34.2 \%)$ & $35(30.7 \%)$ & 114 & \\
\hline & $\geq 110$ & $5(4.38 \%)$ & $35(30.7 \%)$ & $74(64.9 \%)$ & 114 & \\
\hline & Total & 93 & 87 & 120 & 300 & \\
\hline
\end{tabular}

Table 11 shows 56 newborn babies were admitted in NICU, in which $38(67.85 \%)$ were of the mothers who had serum LDH levels $\geq 800 \mathrm{IU} / \mathrm{L}$ (Chi square $=29.4$, $\mathrm{p}$ value $=4.1)$ showing an adverse perinatal outcome.

Table 12 show the perinatal outcome .219 babies were alive and well. 28 babies (66.7\%) whose mother had serum LDH level > 800 IU/L had fetal distress. The incidence of acute respiratory distress syndrome (ARDS), preterm, IUGR, LBW, IUD and neonatal death increased with rising levels of serum LDH levels. In perinatal outcome, Yates' chi square $=282.154$, Yates' $\mathrm{P}$ value $=0$.

Table 13 shows the maternal morbidity in relation to level of serum LDH levels. There was 1 maternal mortality in our study. Maximum maternal morbidity was seen in the group where serum LDH was $>800$ IU/L. In patients with serum LDH >800 IU/L, abruption placentae 
was seen in $6(4.6 \%)$, injury in $4(3.07 \%)$, acute renal failure in 5 cases $(3.8 \%)$, DIC in 1 case $(0.76 \%)$. Jaundice in 4 cases $(3.07 \%)$, HELLP in $3(2.30 \%)$, Psychosis in 2 $(1.5 \%)$, eclampsia in 5 cases $(3.8 \%)$, CVA in 1 case only
$(0.76 \%)$ whereas patients where serum LDH was < 600IU/L, not a single case of ARF, DIC, HELLP, CVA or eclampsia was noted.

Table 10: Birth weight of neonates in relation to different levels of serum LDH (IU/L).

\begin{tabular}{|lllll|l|}
\hline Birth weight of babies $(\mathrm{kg})$ & $<600 \mathrm{IU} / \mathrm{L}$ & $600-800 \mathrm{IU} / \mathrm{L}$ & $>800 \mathrm{IU} / \mathrm{L}$ & Total \\
\hline$>2.5 \mathrm{~kg}$ & $80(41.2 \%)$ & $56(28.8 \%)$ & $58(29.8 \%)$ & 194 & Yates' chi \\
\hline $2.5-1.5 \mathrm{~kg}$ & $10(10.7 \%)$ & $28(30.1 \%)$ & $55(59.1 \%)$ & 93 & square $=33.68$, \\
\hline$<1.5 \mathrm{~kg}$ & $2(15.3 \%)$ & $2(15.3 \%)$ & $9(69.2 \%)$ & 13 & Yates' P value \\
\hline Total & $\mathbf{9 2}$ & $\mathbf{8 6}$ & $\mathbf{1 2 2}$ & $\mathbf{3 0 0}$ \\
\hline
\end{tabular}

Table 11: Neonatal admission to NICU in relation to level of serum LDH (IU/L).

\begin{tabular}{|llllll|}
\hline Admission to NICU & $<600 \mathrm{IU} / \mathrm{L}$ & $600-800 \mathrm{IU} / \mathrm{L}$ & $>800 \mathrm{IU} / \mathrm{L}$ & Total & Chi square $=$ \\
\hline Yes & $3(5.37 \%)$ & $15(26.78 \%)$ & $38(67.85 \%)$ & 56 & 29.409, P value \\
\hline No & $92(37.70 \%)$ & $72(29.50 \%)$ & $80(32.8 \%)$ & 244 & $=4.1$ \\
\hline Total & $\mathbf{9 5}$ & $\mathbf{8 7}$ & $\mathbf{1 1 8}$ & $\mathbf{3 0 0}$ \\
\hline
\end{tabular}

Table 12: Perinatal outcome in relation to level of serum LDH (IU/L).

\begin{tabular}{|lllll|}
\hline Perinatal outcome & $<600 \mathrm{IU} / \mathrm{L}$ & $600-800 \mathrm{IU} / \mathrm{L}$ & $>800 / \mathrm{I} / \mathrm{L}$ & Total \\
\hline Alive and well & $178(81.2 \%)$ & $28(12.7 \%)$ & $13(5.9 \%)$ & 219 \\
\hline Fetal distress & $5(11.9 \%)$ & $9(21.4 \%)$ & $28(66.6 \%)$ & 42 \\
\hline ARDS & $0(0 \%)$ & $2(25 \%)$ & $6(75 \%)$ & 8 \\
\hline Preterm & $5(6.1 \%)$ & $23(28.3 \%)$ & $53(65.4 \%)$ & 81 \\
\hline IUGR & $2(8.3 \%)$ & $9(37.5 \%)$ & $13(54.1 \%)$ & 24 \\
\hline LBW & $12(11.35)$ & $30(28.3 \%)$ & $64(60.3 \%)$ & 106 \\
\hline Early IUD & $0(0 \%)$ & $1(50 \%)$ & $1(50 \%)$ & 2 \\
\hline Late IUD & $3(13 \%)$ & $6(26 \%)$ & $14(60.8 \%)$ & 23 \\
\hline Neonatal death & $1(4.5 \%)$ & $4(18.1 \%)$ & $17(77.2 \%)$ & 22 \\
\hline
\end{tabular}

Table 13: Maternal morbidity in relation to level of serum LDH (IU/L).

\begin{tabular}{|lllll|}
\hline $\begin{array}{l}\text { Serum LDH } \\
\text { Maternal morbidity } \downarrow\end{array}$ & $<600$ IU/L $(\mathrm{n}=56)$ & $600-800 \mathrm{IU} / \mathrm{L}(\mathrm{n}=1 \mathrm{14})$ & $>800 \mathrm{IU} / \mathrm{L}(\mathrm{n}=130)$ & Total \\
\hline Anemia & $48(85.7 \%)$ & $98(85.9)$ & $108(83.0 \%)$ & 254 \\
\hline PPH & $3(3 \%)$ & $10(8.7 \%)$ & $6(4.6 \%)$ & 19 \\
\hline Abruptio & $1(1.7 \%)$ & $4(3.5 \%)$ & $6(4.6 \%)$ & 11 \\
\hline Injury & 0 & $1(0.8 \%)$ & $4(3.07 \%)$ & 5 \\
\hline ARF & 0 & 0 & $5(3.8 \%)$ & 5 \\
\hline DIC & 0 & 0 & $1(.76 \%)$ & 1 \\
\hline Jaundice & 0 & $3(2.63 \%)$ & $4(3.07 \%)$ & 7 \\
\hline HELLP & 0 & 0 & $3(2.30 \%)$ & 3 \\
\hline Psychosis & 0 & 0 & $2(1.5 \%)$ & 2 \\
\hline CVA & 0 & 0 & $1(.76 \%)$ & 1 \\
\hline Eclampsia & 0 & 0 & $5(3.8 \%)$ & 5 \\
\hline Maternal mortality & 0 & 0 & $1(0.76 \%)$ & 1 \\
\hline
\end{tabular}

\section{DISCUSSION}

Pre-eclampsia is a multisystem disorder that is specific to pregnancy. The prevention of severe pre eclampsia and eclampsia has become the main problem to prevent the complications of pregnancy .In order to prevent it ,we must diagnose the disease at the earliest. Therefore, there is need for a marker which can be evaluated as a biochemical marker for pre-eclampsia. 
In present study, majority of the patients belonged to younger age group: between 18-25 years. This was also observed by Jha $\mathrm{N}$ et al and by Gandhi $\mathrm{M}$ et al. ${ }^{1,2}$ Jaiswar SP et al, found that maximum patients in their study belonged to the age group 21 to 30 years. ${ }^{3}$

Most of the patients under this study belonged to rural background $(76 \%)$. This could be because in Jharkhand, most of the population resides in rural area. In our study, most of the patients $(85.3 \%)$ were unbooked - mostly due to illiteracy, less awareness, communication difficulty and lack of infrastructure in healthcare segment. Preeclampsia is commonly seen in primigravida (55-56\%). This was also observed by Jaiswar SP et al, Sreelatha et al, Hak $\mathrm{J}$ et al and Umasatyasri et al. ${ }^{3-6}$

In present study, significantly higher levels of LDH were observed with increasing severity of the disease. The progressively increased LDH level in pre-eclampsia indicates progression of cellular injury with severity of this disorder.

Jaiswar SP et al, also demonstrated a significant rise in the LDH levels with increasing severity of the disease ( $\mathrm{P}$ <0.001). ${ }^{3}$ This was also observed by Qublan et al, Aziz R and Mahboob T et al, Sonagra AD et al, Sarkar PD et al, Sonowal et al, Afroz $\mathrm{R}$ et al, Hazari NR et al, Md Sbiullah et al, Agrawal $\mathrm{P}$ et al, Jha $\mathrm{N}$ et al and Qubran HS et al. ${ }^{1,7-17}$

In this study, systolic and diastolic BP were significantly higher in patients with higher serum LDH levels .Similar reports were shown by Jaiswar SP et al, Aziz R, Mahboob T et al, Sarkar PD et al, Md Sabiullah et al,

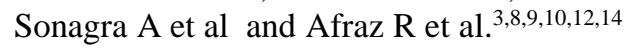

In a study conducted by Martin JN et al, a high serum level of LDH (1400 IU/L) were shown to have a high predictive value for significant maternal morbidity. ${ }^{16}$ Catanzerite VA et al reported that subgroup of patients who had elevated levels of LDH manifested with haemolysis, elevated liver enzymes, low platelet count (HELLP) syndrome and were at high risk for developing maternal mortality. ${ }^{17}$ Demir SC et al in their study concluded that there was a relationship between maternal complications and high LDH levels and was statistically significant. ${ }^{18}$ Jaiswar SP et al also observed that there was significant increase in maternal morbidity with increasing serum LDH levels $(\mathrm{P}<0.001) .{ }^{3}$ In a study conducted by Umasatyasri $\mathrm{Y}$ et al, they observed an increase in maternal morbidity and fetal outcome with increasing serum LDH levels. They also observed that higher serum LDH levels were associated with increased incidence of maternal complications like abruption placentae, renal failure, HELLP syndrome, CVA etc. ${ }^{19}$

In our study, not only the maternal morbidity was significant but also the fetal outcome was poor in patients having high serum LDH levels. The mean birth weight of babies was low and the percentage of live birth was low in pregnant women with high LDH levels compared to women with lower levels. The neonatal complications and neonatal deaths were high in percentage when compared to women with lower levels of serum LDH.

Few studies showed association of low birth weight of infants with increase in serum LDH levels. ${ }^{9,20}$

In present study, it was observed that maternal morbidity is increased with progression of the disease as reflected by rising serum LDH levels.

In severe pre-eclampsia group (serum LDH levels > $800 \mathrm{IU} / \mathrm{L})$ - PPH occurred in $6(4.6 \%)$, abruption in 6 $(4.6 \%)$, acute renal failure in $5(3.8 \%)$, DIC in $1(0.76 \%)$, jaundice in $4(3.07 \%)$, HELLP in $3(2.3 \%)$, psychosis in $2(1.5 \%)$, CVA in $2(1.5 \%)$, eclampsia in $1(0.76 \%)$ and many patients had more than 1 complications.

There was no maternal mortality in non severe group and 1 maternal death in severe pre-eclampsia patients group.

\section{CONCLUSION}

Pre-eclampsia is a multisystem disorder specific to pregnancy and has many complications. It leads to poor maternal and fetal outcome. The triad of high blood pressure, oedema, albuminuria is neither specific nor sensitive; therefore the search is on for a reliable marker. In present study, LDH has been evaluated as a biochemical marker for pre-eclampsia and as a prognosticator of the disease severity. The observations of the present study shows that the serum LDH levels increased in pre-eclamptic patients and maternal and fetal outcome was poor in patients with high serum LDH levels. So serum LDH is a useful biochemical marker as it reflects severity of and occurrence of complications of pre-eclampsia. Detection of high risk patients with increased levels of LDH mandates close monitoring, prompt and correct management to decrease both maternal and fetal morbidity and mortality. Therefore, we conclude from this study that screening of all cases of pre-eclampsia with serum LDH should be made mandatory.

\section{ACKNOWLEDGMENTS}

Authors would like to thank patients for their cooperation.

Funding: No funding sources

Conflict of interest: None declared

Ethical approval: The study was approved by the Institutional Ethics Committee

\section{REFERENCES}

1. Jha N, Padhi M, Mishra A, Misra L, Nayak AK. Study on serum lactate dehydrogenase (LDH) as a biochemical marker for maternal and perinatal 
outcome in preeclampsia and eclampsia. Indian Obstet Gynaecol. 2015;5(4):6-12.

2. Gandhi M, Chavda R, Saini HB. Comparative study of serum LDH and uric acid in hypertensive verses normotensive pregnant women. Int $\mathrm{J}$ Biomed Res. 2015;6(1):25.

3. Jaiswar SP, Gupta A, Sachan R. Lactic dehydrogenase: a biochemical marker for pre eclampsia-eclampsia. J Obstet Gynaecol India. 2011;61(6):645-8.

4. Sreelatha. Estimation of serumlactate dehydrogenase and uric acid in preeclampsia. Int $\mathbf{J}$ Adv Case Reports. 2015;2(7):447-9.

5. Hak J, Gupta S. LDH Levels in pregnancy and its association with severity of the disease and fetomaternal outcome in pre-eclampsia and eclampsia. JK Science. 2015;17(3):110.

6. Umasatyasri Y, Vani I, Shamita P. Role of LDH (Lactate dehydrogenase) in preeclampsia - eclampsia as a prognostic marker : an observational study. Inte Arch Integrated Med. 2015;2(9):88-93.

7. Qublan HS, Ammarin V, Bataineh O. Lactic dehydrogenase as a biochemical marker of adverse pregnancy outcome in severe preeclampsia. Med Sci Monit. 2005;11(8):CR 393-7.

8. Aeziz R, Mahboob T. Relation between preeclampsia and cardiac enzymes. Arya Atherosclerosis J. 2008;4(1):29-38.

9. Sonagra AD, Dattatreya K, Jayaprakash M. Serum LDH, ALP and uric acid in hypertensive disorders of pregnancy. Int J Pharm Bio Sci. 2012;2(3):201-9.

10. Sarkar PD, Sogani S. Evaluation of serum lactate dehydrogenase and gama glutamyl transferase in preeclamptic pregnancy and its comparison with normal pregnancy in third trimester. Int $\mathbf{J}$ Res Med Sci. 2013;1(14):365-8.

11. Sonowal R. Significance of lactate dehydrogenase and aspartate transaminase as biochemical markers and as predictors of severity of pregnancy-induced hypertension and its complications. J Evidence Based Med Health. 2017;4(20):12-20.

12. Rukhsana A. Serum Lactate Dehydrogenase (LDH) level in severe preeclampsia. J Bangladesh Soc Physiol. 2015;10(2):71-5.

13. Hazari NR. Study of serum hepatic enzymes in preeclampsia. Int $\mathbf{J}$ Current Med Applied Sci. 2014;(1):1-8.

14. Sabiullah. Study of serum lactate dehydrogenase and uric acid in preeclampsia. Int $\mathrm{J}$ Pharma Res Biosci. 2015;4(3):160-6.

15. Agarwaal P. Serum LDH in preeclampsia and eclampsia and maternal outcomes. SJAMS. 2016;4(6C):2052-5.

16. Martin JN, May WL, Magann EF. Early risk assessment of severe preeclampsia: Admission battery of symptoms and laboratory tests to predict likelihood of subsequent significant maternal morbidity. Am J Obstet Gynaecol. 1999;180:140714.

17. Catenzerite VA, Steinberg SM, Mosley CA. Severe preeclampsia with fulminant and extreme elevation of aspartate aminotrans ferase and lactate dehydrogenase levels. Am J Perinatol. 1995;12:3103 .

18. Demir SC, Evruke C, Ozgunen FT. Factors that influence morbidity, and mortality in severe preeclampsia, eclampsia and HELLP syndrome. Saudi Med J. 2006;27:1015-8.

19. He S, Bremme K, Kallner A, Blomback M. Increased concentrations of lactate dehydrogenase in pregnancy with preeclampsia; a predictor for birth of small for gestational age infants. Gynaecol Obstet Invest. 1995;39:234-8.

Cite this article as: Mehta M, Parashar M, Kumar R. A Serum LDH: a prognostic factor in pre-eclampsia. Int J Reprod Contracept Obstet Gynecol 2019;8:2792-8. 